\title{
Dampak Penggunaan Fungisida Sintetik pada Kelimpahan Cendawan Endofit Tanaman Padi
}

\section{(The Impact of Synthetic Fungicide Application on Abundance of Endophytic Fungi of Rice)}

\author{
Rika Estria Gurusinga ${ }^{1}$, Lilik Retnowati ${ }^{2}$, Suryo Wiyono ${ }^{3}$, Efi Toding Tondok ${ }^{3 *}$
}

(Diterima Juli 2019/Disetujui Mei 2020)

\begin{abstract}
ABSTRAK
Aplikasi fungisida di pertanaman padi berpotensi berpengaruh negatif pada organisme nontarget, termasuk cendawan endofit. Akan tetapi, pengaruh fungisida sintetik pada cendawan endofit pada tanaman padi belum pernah dilaporkan. Tujuan penelitian ini adalah mempelajari keanekaragaman dan kelimpahan cendawan endofit padi karena penggunaan fungisida sintetik. Ada dua perlakuan dalam penelitian ini, yaitu fungisida nonsistemik (mankozeb) dan fungisida sistemik (difenokonazol) yang dibandingkan dengan kontrol (tanpa fungisida). Isolasi cendawan endofit dan aplikasi fungisida dilakukan setiap minggu pada saat tanaman berumur 3-10 minggu setelah tanam (MST). Variabel yang diamati ialah total segmen padi yang dikolonisasi cendawan endofit, frekuensi kolonisasi cendawan endofit, yang dilanjutkan dengan identifikasi dan analisis indeks keanekaragamannya. Hasil penelitian menunjukkan ada peningkatan kolonisasi cendawan endofit di setiap pertambahan umur tanaman. Keanekaragaman cendawan endofit lebih tinggi pada batang $\left(H^{\prime}=0,00-1,35\right)$ dibandingkan dengan daun $\left(H^{\prime}=0,00-0,98\right)$. Jenis cendawan endofit yang paling sering ditemukan di setiap isolasi segmen padi ialah Acremonium, Curvularia, Fusarium, Helminthosporium, Nigrospora, Penicillium, dan Mucor. Kedua fungisida tidak memengaruhi secara nyata persentase kolonisasi dan keanekaragaman cendawan endofit. Pada awal pertanaman (4-6 MST) terjadi penurunan persentase kolonisasi cendawan endofit pada batang. Jika dilihat dari persentase kolonisasi masing-masing genus cendawan, Nigrospora dan Fusarium mengalami penurunan dengan Difenokonazol pada batang selama fase vegetatif.
\end{abstract}

Kata kunci: difenokonazol, keanekaragaman, kolonisasi, komunitas, mankozeb

\section{ABSTRACT}

Application of fungicides to control rice diseases potentially have adverse effect on non target organisms including endophytic fungi. Unfortunately, information of fungicide effect on endophytic fungi on rice is still limited. The purpose of this research was to study the diversity and abundance of endophytic fungi on rice plant because of application of synthetic fungicides. There were two treatments in this study: non systemic fungicide (mankozeb) and systemic fungicide (difenoconazole) which were compared to control (without fungicide). Isolation of endophytic fungi and application of fungicides were conducted every week started at aged of 3 to 10 weeks after planting. Variables observed were total segment of rice colonized by endophytic fungi, colonization frequency of endophytic fungi, continued by identification and analysis of the diversity of endophytic fungi. This study showed that there was an increase in colonization of endophytic fungi with an increase of plant ages. The diversity of endophytic fungi was higher in stems than in leaves with the value of $\mathrm{H}^{\prime}$ is $0.00-1.35$ and $0.00-0.98$ respectively. The most common types of endophytic fungi appear in each isolation of rice segments were Acremonium, Curvularia, Fusarium, Helminthosporium, Nigrospora, Penicillium, and Mucor. Both fungicides do not significantly affect the percentage of colonization and diversity of endophytic fungi. At the beginning of planting (4-6 MST) there was a decrease in the percentage of endophytic fungal colonization in the stem. From the percentage of colonization of each genus of fungi, Nigrospora and Fusarium decreased significantly with difenoconazole on the stem during the vegetative phase.

Keywords: colonization, community, difenoconazole, diversity, mancozeb

1 Sekolah Pascasarjana, Fakultas Pertanian, Institut Pertanian Bogor, Kampus IPB Darmaga, Bogor 16680

2 Balai Besar Peramalan Organisme Pengganggu Tumbuhan, Jl. Raya Kaliasin Tromol Pos 1, Jatisari, Pangulah Utara, Kec. Kotabaru, Karawang 41374

3 Departemen Proteksi Tanaman, Fakultas Pertanian, Institut Pertanian Bogor, Kampus IPB Darmaga, Bogor 16680

*Penulis Korespondensi: Email: ettondok@apps.ipb.ac.id

\section{PENDAHULUAN}

Fungisida telah digunakan secara luas untuk mengendalikan penyakit yang disebabkan oleh cendawan patogen. Akan tetapi, fungisida bukan hanya berpengaruh pada cendawan patogen, tetapi juga berpengaruh pada organisme lain, seperti cendawan endofit. Mohandoss \& Suryanarayanan (2009) melaporkan bahwa fungisida sistemik, seperti hexa- 
conazole, mengurangi frekuensi kolonisasi cendawan endofit pada daun Mangifera indica L. dibandingkan dengan tanpa fungisida. Fungisida benomyl dan thiophanate-methyl menurunkan jumlah endofit Neotyphodium Iollii dan Neotyphodium coenophialum pada tanaman sejenis rumput-rumputan (Saiga et al. 2003). Lebih dari 30 fungisida telah terdaftar untuk digunakan dalam pengendalian penyakit padi, beberapa di antaranya adalah azoxystrobil, carbendazim, khlorothalonil, difenokonazol, isoprotiolan, mankozeb, dan propineb (Kumar et al. 2013). Sudir et al. (2002) dalam percobaannya menunjukkan bahwa benomil 50 WP dan mankozeb 80\% efektif dalam mengendalikan penyakit blas pada padi. Beberapa fungisida lain, seperti carbendazim $50 \%$, isoprotiolan $40 \%$, dan difenokonazol $25 \%$ juga efektif dalam mengendalikan penyakit blas. Keanekaragaman cendawan endofit yang tinggi pada lahan dengan pengelolaan hama terpadu (PHT) meningkatkan hasil produksi padi dibandingkan dengan pengelolaan konvensional (Ariyanto et al. 2013).

Cendawan endofit merupakan mikroorganisme yang hidup di dalam jaringan tanaman yang sehat, yang dapat berperan melindungi tanaman dari hama dan patogen, serta mendukung proses penyerapan nutrien (Afandhi et al. 2018). Penelitian tentang cendawan endofit sudah banyak dilakukan sebelumnya dan beberapa mampu memberikan pengaruh positif pada tanaman. Beberapa cendawan endofit yang berhasil diisolasi dari berbagai bagian tanaman padi adalah Aspergillus, Curvularia, Gilmaniella, Arthrobotrys foliicola, Streptomyces sp., Chaetomium globosum, Penicillium chrysogenum, Fusarium oxysporum, dan Cladosporium cladosporioides (Naik et al. 2009; Zakaria et al. 2010). Pada pengujian secara in vivo, cendawan endofit yang berhasil diisolasi dari tanaman padi mampu menekan keparahan penyakit dan meningkatkan pertumbuhan tanaman padi (Sucipto 2016; Waruwu et al. 2016).

Keberadaan cendawan endofit akan dipengaruhi oleh keadaan lingkungan sekitarnya, seperti penggunaan fungisida sintetik. Oleh karena itu, perlu dilakukan penelitian mengenai pengaruh penggunaan fungisida sintetik pada cendawan endofit padi. Penelitian ini bertujuan untuk menganalisis keanekaragaman dan kelimpahan cendawan endofit pada tanaman padi dengan penggunaan fungisida sintetik.

\section{METODE PENELITIAN}

Penelitian dilaksanakan di Balai Besar Peramalan Organisme Pengganggu Tumbuhan Jatisari, Karawang dan Laboratorium Mikologi Tumbuhan, Departemen Proteksi Tanaman, Fakultas Pertanian, IPB, Bogor. Penelitian dilaksanakan pada bulan Juni sampai Desember 2018.

Percobaan di lapangan disusun dengan menggunakan rancangan acak kelompok (RAK) dengan faktor tunggal. Percobaan terdiri atas dua taraf faktor, yaitu fungisida nonsistemik (Dithane M-45, b.a mankozeb 80\%), fungisida sistemik (Score $250 \mathrm{EC}$, b.a difenokonazol), dan kontrol (tanpa fungisida). Setiap perlakuan diulang lima kali sehingga terdapat 15 satuan percobaan.

Lahan percobaan berbentuk petakan, yang terdiri atas 15 petak dengan ukuran per-petak $5 \mathrm{~m} \times 5 \mathrm{~m}$. Varietas padi yang digunakan adalah Ciherang dengan jarak tanam $25 \times 25 \mathrm{~cm}$. Umur tanaman dipembibitan hingga pindah tanam ialah 20 hari setelah tanam (hst). Pemeliharaan tanaman berupa pemupukan dan penyiangan gulma dilakukan tiga kali selama musim tanam. Aplikasi fungisida dilakukan setiap minggu pada tanaman berumur 3-10 minggu setelah tanam (MST). Dosis fungisida yang digunakan mengacu pada dosis anjuran pemakaian, yaitu $2 \mathrm{~g} \mathrm{~L}^{-1}$ untuk mankozeb dan $300 \mathrm{Ml} \mathrm{ha}^{-1}$ untuk difenokonazol dengan volume larutan semprot masing-masing $500 \mathrm{~L} \mathrm{ha}^{-1}$.

Isolasi cendawan endofit dilakukan setiap minggu yang dimulai pada saat tanaman berumur 3-10 MST dan dilakukan sebelum aplikasi fungisida. Pengambilan sampel contoh dilakukan pada 3 rumpun tanaman yang telah ditetapkan secara acak dan setiap rumpun dipilih 3 anakan. Setiap anakan diambil masing-masing 1 segmen daun dan batang.

Metode isolasi cendawan endofit mengikuti metode Schulz et al. (1993) yang dimodifikasi. Anakan padi yang sehat dicuci pada air yang mengalir untuk membersihkan kotoran-kotoran yang menempel. Potongan daun dan batang $( \pm 3 \mathrm{~cm})$ disterilisasi permukaan secara berseri dengan cara merendamnya pada etanol $70 \%$ selama 30 detik, kemudian pada $\mathrm{NaOCl} 1 \%$ selama 60 detik, kemudian kembali pada etanol 70\% selama 30 detik, lalu dibilas dengan akuades steril tiga kali, kemudian dikering-anginkan di atas kertas saring. Uji kesterilan dilakukan untuk mengetahui tingkat sterilisasi permukaan bagian tanaman yang diisolasi dengan cara potongan tersebut ditempelkan pada media Potato Dextrose Agar (PDA) dari setiap sisi permukaannya dan diinkubasi selama 3-5 hari. Bila tidak ada mikrob yang tumbuh pada media PDA bekas tempelan, berarti sterilisasi permukaan berhasil. Potongan jaringan yang telah disterilisasi dipotong lebih kecil $\pm 0,5 \mathrm{~cm}$ dan diletakkan pada media Malt Extract Agar (MEA) dan diinkubasi selama 7 hari. Pemurnian isolat cendawan endofit yang tumbuh dilakukan pada media PDA.

Identifikasi cendawan endofit dilakukan dengan menggunakan buku panduan identifikasi Domsch et al. (1980); Watanabe (2002). Variabel yang diamati dan analisis data:

- Kolonisasi total endofit dihitung dengan rumus: \% kolonisasi segmen daun/batang $=a / b \times 100 \%$, dengan $\mathrm{a}=$ jumlah segmen yang ditumbuhi cendawan endofit; $b=$ total segmen yang diamati. Total segmen jaringan yang diamati dihitung berdasarkan 3 anakan $\times 3$ rumpun = masing-masing 9 potongan jaringan daun dan batang padi setiap ulangan. 
- Frekuensi relatif kolonisasi cendawan endofit secara individual dihitung dengan rumus: \% kolonisasi $=\mathrm{ni} / \mathrm{b} \times 100 \%$, dengan $\mathrm{ni}=$ jumlah segmen yang ditumbuhi cendawan endofit ke-i; $b=$ total segmen yang diamati.

- Indeks keanekaragaman Shanon-Wienner (Magurran 1988) dihitung dengan rumus: $H^{\prime}=$ $-\sum_{\mathrm{i}=1}^{\mathrm{s}} \mathrm{Pi} \ln \mathrm{Pi}$, dengan $\mathrm{H}^{\prime}=$ indeks keanekaragaman Shanon-Wienner; $\mathrm{Pi}=\mathrm{ni} / \mathrm{N} ; \mathrm{ni}=$ jumlah spesies kei; $\mathrm{N}=$ jumlah total kelimpahan; $\mathrm{S}=$ jumlah spesies.

- Indeks kesamaan Sorensen (Magurran 1988) dihitung dengan rumus: $\mathrm{Cs}=2 \mathrm{j} /(\mathrm{a}+\mathrm{b})$, dengan $\mathrm{Cs}=$ indeks Sorensen; $j=$ jumlah jenis terkecil yang sama dari dua perlakuan yang berbeda; $a=$ jumlah jenis yang terdapat di perlakuan $a ; b=$ jumlah jenis yang terdapat di perlakuan b. Indeks Sorensen disajikan dalam bentuk MDS (multidimensional scalling) menggunakan R-statistik.

Data yang diperoleh diuji dengan analisis ragam dan apabila terdapat pengaruh yang nyata maka dilakukan uji lanjut dengan uji Student Newman Keul (SNK).

\section{HASIL DAN PEMBAHASAN}

\section{Persentase Kolonisasi Cendawan Endofit}

Hasil penelitian menunjukkan bahwa persentase kolonisasi cendawan endofit yang tumbuh dari segmen daun dan batang padi mengalami peningkatan seiring dengan pertambahan umur tanaman. Puncak peningkatan terjadi di minggu ke-8, yang mencapai $66-93 \%$ pada daun dan $77-86 \%$ pada batang (Gambar 1). Peningkatan kolonisasi cendawan endofit akan memberikan pengaruh yang menguntungkan bagi tanaman padi karena cendawan endofit ada yang bermanfaat dalam pertumbuhan tanaman inang. Fuchs et al. (2017) juga menemukan peningkatan kolonisasi endofit Epichloe festucae var Lolii pada tanaman Lolium perenne yang lebih tua. Peningkatan tersebut ditunjukkan dengan peningkatan konsentrasi alkaloid yang dihasilkan endofit yang mampu melindungi inang dari serangga hama herbivora. Pada Gambar 1 ditunjukkan adanya penurunan persentase kolonisasi cendawan endofit pada batang pada saat tanaman berumur muda (4-6 MST). Penurunan tersebut akan mengurangi metabolit yang diinduksi oleh cendawan endofit pada tanaman padi sebagai salah satu bentuk pertahanan dalam melawan serangga hama.

\section{Indeks Keanekaragaman dan Indeks Kesamaan Cendawan Endofit}

Berdasarkan indeks keanekaragaman ShanonWienner $\left(H^{\prime}\right)$ bahwa ragam cendawan endofit lebih tinggi pada batang dibandingkan dengan pada daun. $\mathrm{Hal}$ ini terjadi demikian mungkin karena batang merupakan mikrohabitat yang cocok untuk perkembangan cendawan endofit, yang terkait dengan ketersediaan sumber $\mathrm{C}$ dan $\mathrm{N}$ untuk mendukung pertumbuhan cendawan. Batang yang lebih dekat dengan perkarakan tanaman (rizosfer) dan produkproduk dari fotosintesis yang diangkut ke bawah melalui floem dapat mencapai batang terlebih dahulu sebelum mencapai akar (Koomnok et al. 2007).

Nilai H' cendawan endofit daun berkisar antara $0,00-0,98$ dan H' batang berkisar 0,00-1,35 (Gambar 2). Menurut Krebs (1989), nilai $H^{\prime}<1$ termasuk ke dalam kategori keanekaragaman rendah, $1<\mathrm{H}^{\prime}<3$ termasuk ke dalam kategori keanekaragaman sedang, dan $\mathrm{H}^{\prime}>3$ termasuk ke dalam kategori keanekaragaman tinggi. Berdasarkan kriteria tersebut, keanekaragaman cendawan endofit pada daun tergolong rendah, sedangkan pada batang tergolong rendah hingga sedang. Berdasarkan hasil ini dapat diasumsikan bahwa terdapat cendawan yang sangat dominan pada daun. Teknik isolasi cendawan endofit juga memengaruhi hasil isolasi dari suatu komunitas. Metode dengan penanaman jaringan pada media membutuhkan waktu yang lama dan beberapa cendawan yang membutuhkan persyaratan pertumbuhan khusus sering tidak terlihat (Gotz et al. 2006). Malt Extract Agar (MEA) merupakan media yang umum digunakan dalam isolasi
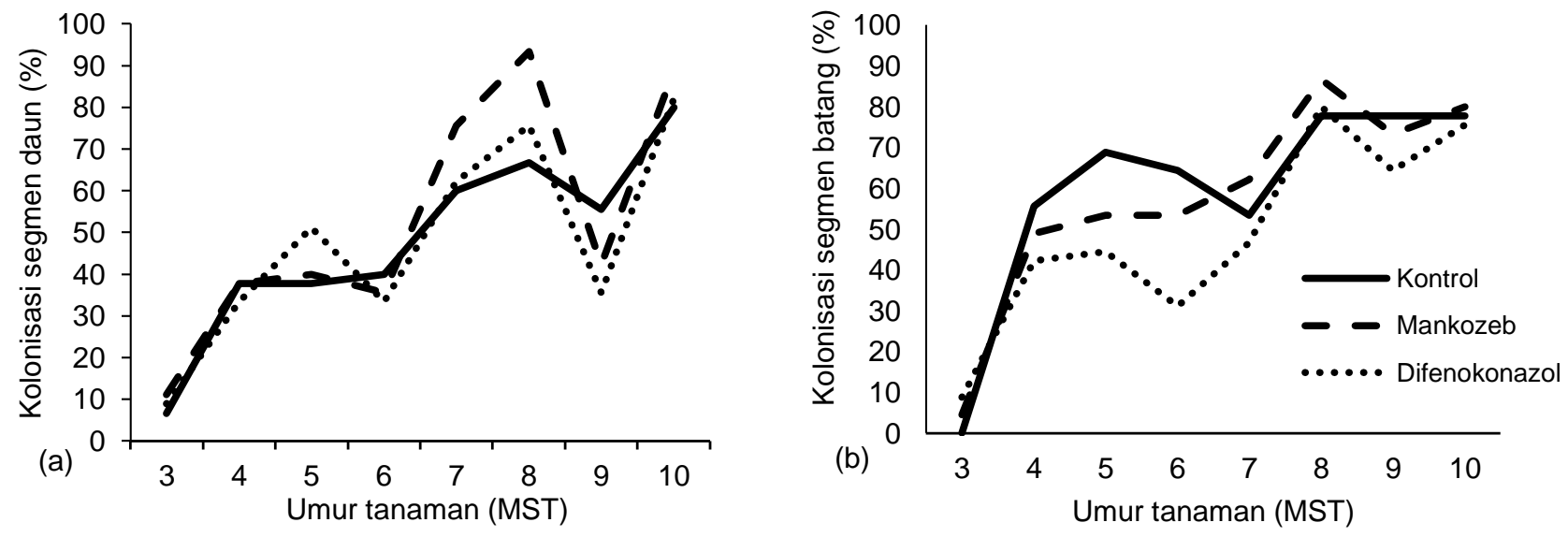

Gambar 1 Persentase kolonisasi segmen padi yang ditumbuhi cendawan endofit pada: a) Daun dan b) Batang. 

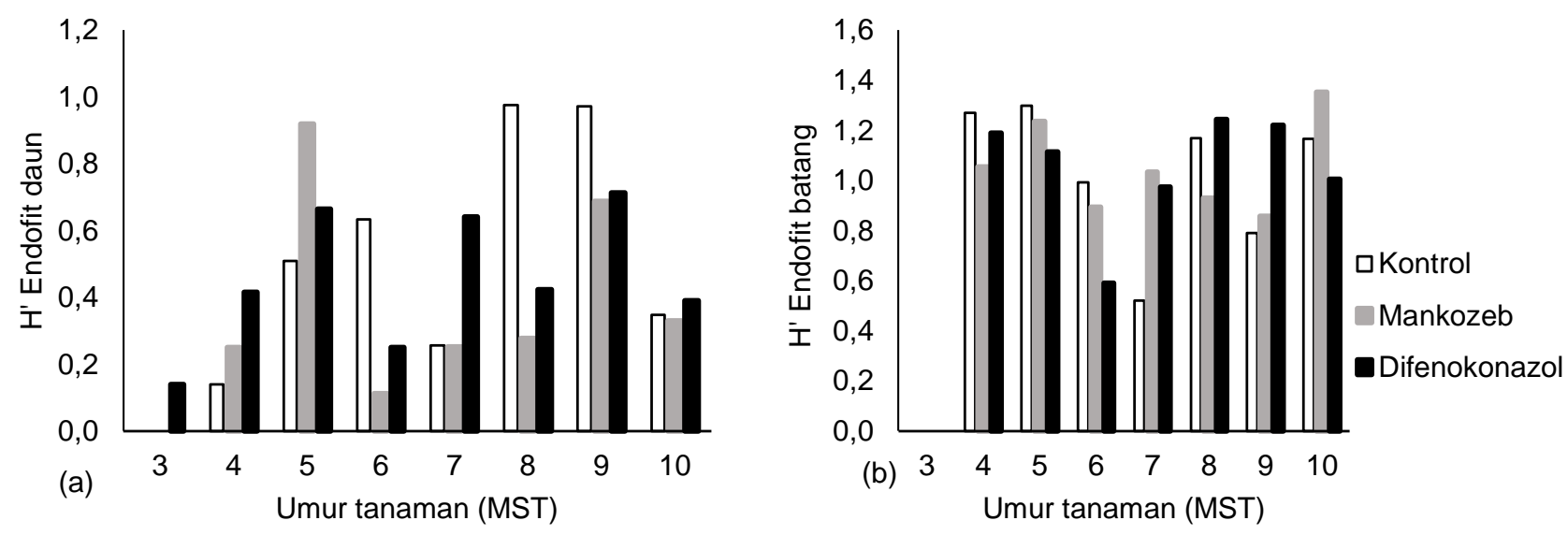

Gambar 2 Indeks keanekaragaman Shanon-Wiener ( $\left.H^{\prime}\right)$ cendawan endofit padi pada: a) Daun dan b) Batang.

cendawan endofit (Arnold et al. 2001). MEA memiliki daya tahan yang lebih lama dibandingkan dengan media lain sehingga cendawan endofit yang membutuhkan waktu lama untuk tumbuh, nutrisinya masih tersedia. Selain itu, MEA juga membantu dalam pertumbuhan cendawan dan yeast, tetapi tidak untuk bakteri. Dengan demikian, bakteri yang tidak termasuk ke dalam objek penelitian ini dapat diminimalkan pertumbuhannya. Jumlah sampel dan ukuran potongan jaringan pada penelitian ini juga sudah cukup memenuhi standar isolasi cendawan endofit pada umumnya. Mungkin, dengan penam-bahan sampel yang lebih lagi dan penggunaan teknik berbeda dalam pengambilan potongan jaringan dalam satu tanaman bisa jadi pertimbangan dalam isolasi cendawan endofit untuk mendapatkan frekuensi kolonisasi dari setiap genus cendawan yang lebih baik lagi. Semakin banyak jumlah sampel dan semakin kecil ukuran potongan jaringan, cendawan endofit yang diperoleh juga semakin banyak (Gamboa et al. 2002; Sun \& Guo 2012).

Indeks kesamaan Sorensen ditampilkan dalam bentuk multidimensional scaling (MDS) (Gambar 3a dan 3b). Letak titik ordinasi setiap perlakuan baik daun dan batang saling berdekatan. Hal ini menunjukkan bahwa fungisida mankozeb dan difenokonazol tidak memengaruhi jenis cendawan endofit yang mengoIonisasi padi. Titik ordinasi yang berjauhan menunjukkan jenis cendawan endofit yang spesifik dari setiap perlakuan. Cendawan endofit yang hanya ditemukan pada kontrol diduga sensitif terhadap mankozeb dan difenokonazol. Cendawan endofit tersebut di antaranya adalah Alternaria, Helminthosporium 2, Penicillium 9, Cendawan 4 (dari daun), dan Cendawan 6 (dari batang).

Spesies yang hanya ditemukan pada perlakuan mankozeb di daun ialah Aspergillus $\mathrm{sp}$, Helminthosporium 1, dan Penicillium 1, sedangkan yang hanya ditemukan di batang ialah Acremonium 1. Sementara pada perlakuan difenokonazol, spesies yang ditemukan di dauan ialah Trichoderma 1 , Fusarium 3, Penicillium 3, Cendawan 2, Cendawan 3, dan Cendawan 6 , sedangkan spesies yang ditemukan di batang ialah Trichoderma 2, Penicillium 3, Penicillium 5, Helminthosporium 3, dan Cendawan 2. Cendawan endofit spesifik lebih banyak ditemukan pada perlakuan difenokonazol. Akan tetapi, cendawancendawan spesifik tersebut ditemukan dalam jumlah yang rendah. Kemungkinan aplikasi fungisida membatasi penyebaran horizontal endofit di pertanaman.

\section{Kolonisasi Cendawan Endofit Dominan}

Genus dominan yang mengolonisasi tanaman padi ialah Acremonium, Curvularia, Fusarium, Nigrospora, Mucor, Helminthosporium, dan Penicillium. Rata-rata total kolonisasi tujuh genus tersebut mencapai $44-54 \%$ pada daun dan 47-59\% pada batang (Gambar 4 dan 5). Genus Nigrospora, Penicillium, Curvularia, dan Helminthosporium berhasil diisolasi dari jaringan daun umur 3 dan 4 MST. Frekuensi kolonisasi Nigrospora adalah yang paling tinggi, yaitu $\pm 30 \%$, dibandingkan dengan genus lain yang frekuensi kolonisasinya di bawah 5\%. Nigrospora tetap mengolonisasi daun dengan frekuensi paling tinggi hingga minggu ke-8 (Gambar 4). Pada batang tanaman padi umur 3 dan 4 MST berhasil diisolasi cendawan Nigrospora, Acremonium, Mucor, Fusarium, dan Penicillium. Frekuensi kolonisasi paling tinggi ditunjukkan oleh Penicillium yang mencapai $\pm 25 \%$ dan genus lain hanya di bawah $11 \%$. Pada minggu ke-8, frekuensi kolonisasi Acremonium meningkat lebih tinggi dibandingkan dengan genus lain (Gambar 5).

Frekuensi kolonisasi cendawan endofit dapat dipengaruhi oleh banyak faktor, seperti faktor lingkungan. Curah hujan dan kelembapan udara menentukan keberhasilan penyebaran dan perkecambahan spora cendawan endofit. Penyebaran endofit terjadi secara vertikal dan horizontal. Penyebaran endofit secara vertikal terjadi melalui benih dan ditransfer langsung dari induk inang ke keturunannya (Saikkonen et al. 2002). Endofit menyebar secara horizontal melalui penyebaran antar-individu yang berbeda dalam suatu populasi melalui infeksi spora yang ada di udara (Hartley \& Gange 2009). Cendawan endofit yang berhasil diisolasi pada fase awal vegetatif kemungkinan bersifat seed borne dan menyebar secara 

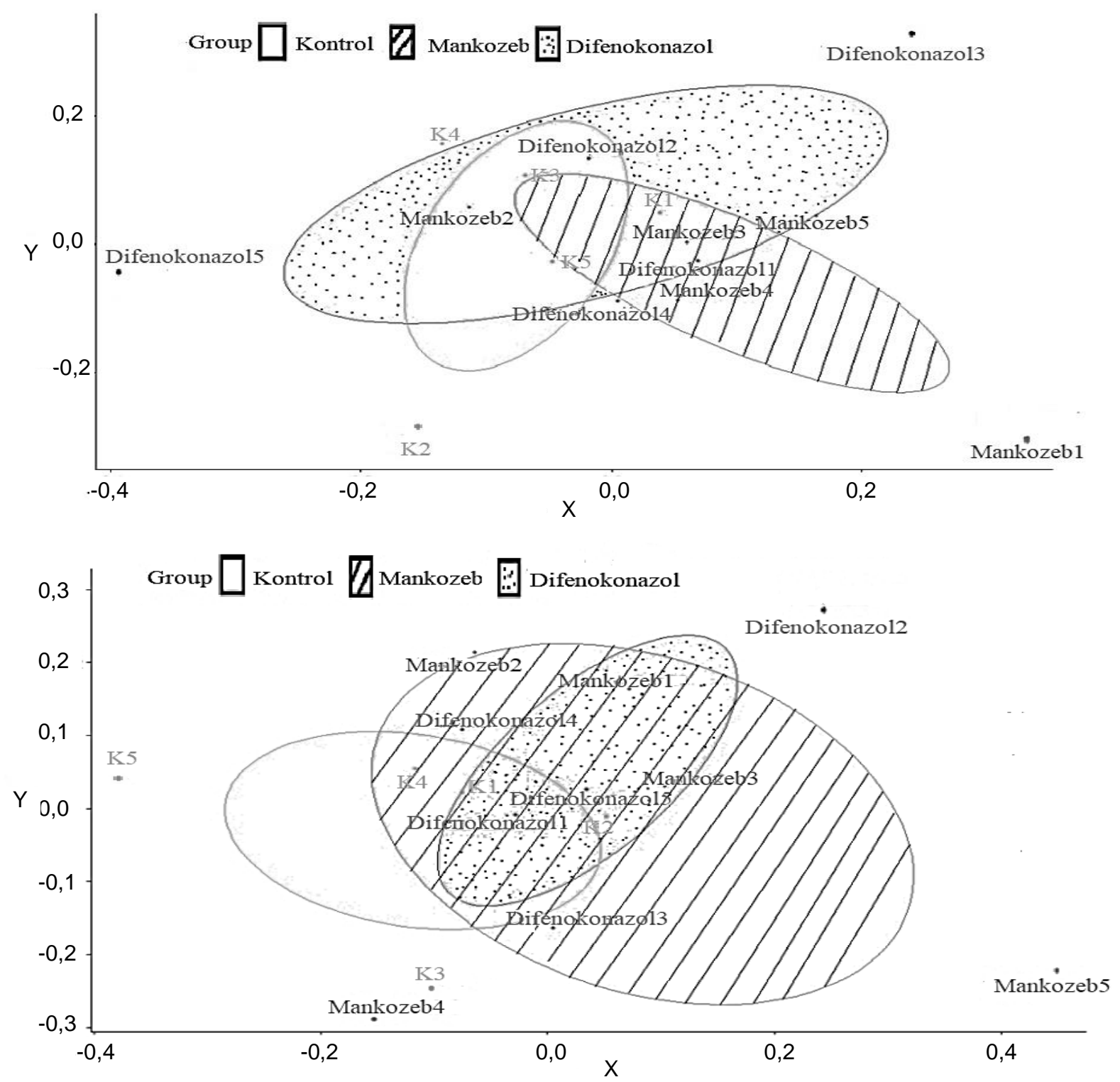

Gambar 3 Kesamaan jenis spesies antar-perlakuan pada a) Daun dan b) Batang dari indeks Sorensen dengan scaling MDS).

vertikal ke seluruh bagian tanaman. Penyebaran secara horizontal membantu cendawan bertahan dan menyebar ke tanaman sekitar sehingga pada fase akhir vegetatif dan fase generatif beberapa cendawan endofit mengalami perubahan frekuensi kolonisasi.

Fungisida meningkatkan frekuensi kolonisasi Nigrospora pada daun secara nyata pada minggu ke8. Frekuensi kolonisasi Nigospora tertinggi pada perlakuan mankozeb adalah sebesar $89 \%$, sedangkan pada perlakuan difenokonazol adalah sebesar $69 \%$. Dua perlakuan tersebut memiliki frekuensi kolonisasi yang lebih tinggi dibandingkan dengan kontrol yang hanya sebesar 44\% (Gambar 4). Hasil ini menunjukkan bahwa Nigrospora diduga tahan terhadap dua fungisida yang digunakan. Selain itu, cendawan lain selain Nigrospora diduga sensitif terhadap fungisida sehingga Nigrospora memiliki peluang yang lebih besar mengolonisasi jaringan daun padi. Perlakuan fungisida pada cendawan endofit lainnya tidak menunjukkan perubahan yang nyata. Akan tetapi, hasil rata-rata frekuensi kolonisasi Acremonium, Penicillium, Curvularia, dan Helminthosporium lebih tinggi pada kontrol dibandingkan dengan pada perlakuan fungisida.

Difenokonazol secara nyata menurunkan frekuensi kolonisasi Fusarium pada batang pada minggu ke-4, ke-5, dan ke-7 dengan rata-rata frekuensi kolonisasi yang rendah, yaitu $0,28 \%$ (Gambar 5). Difenokonazol secara nyata juga menurunkan frekuensi kolonisasi Nigrospora pada minggu ke-6. Beberapa fungisida akan memengaruhi kelimpahan endofit di dalam tanaman dengan tingkat sensitivitas yang bervariasi (Cadez et al. 2010). Malandrakis et al. (2018) melaporkan bahwa cendawan endofit Fusarium solani tidak sensitif terhadap fungisida thiophanate-methyl, fenhexamid, cyprodinil, boscalid, dan mankozeb, tetapi sangat sensitif terhadap fungisida prochloraz, fludioxonil, pyraclostrobin, dan difenokonazol. Hasil 


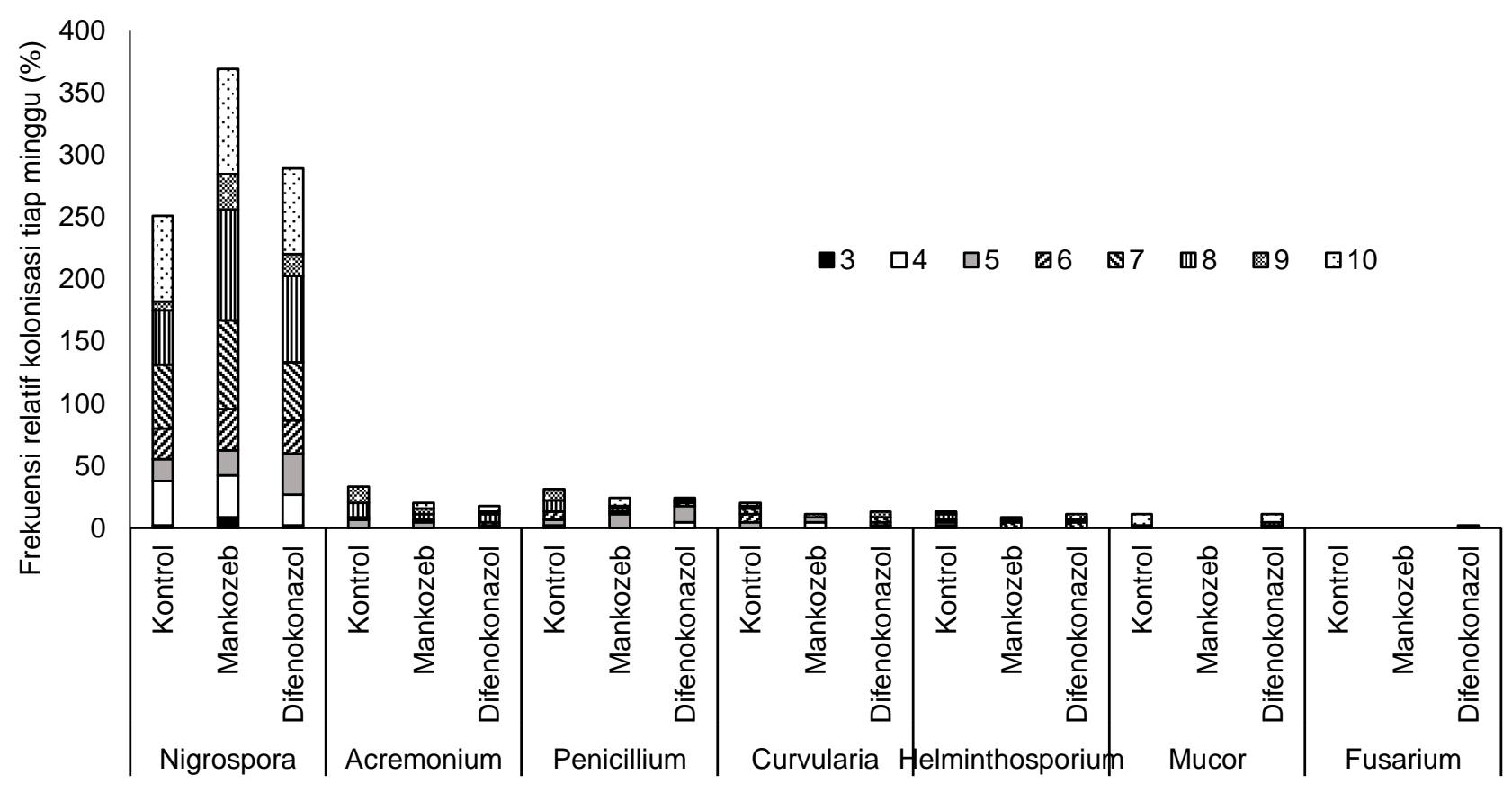

Gambar 4 Frekuensi relatif kolonisasi genus utama cendawan endofit daun padi tiap minggu (3-10 MST) pada tiap perlakuan.

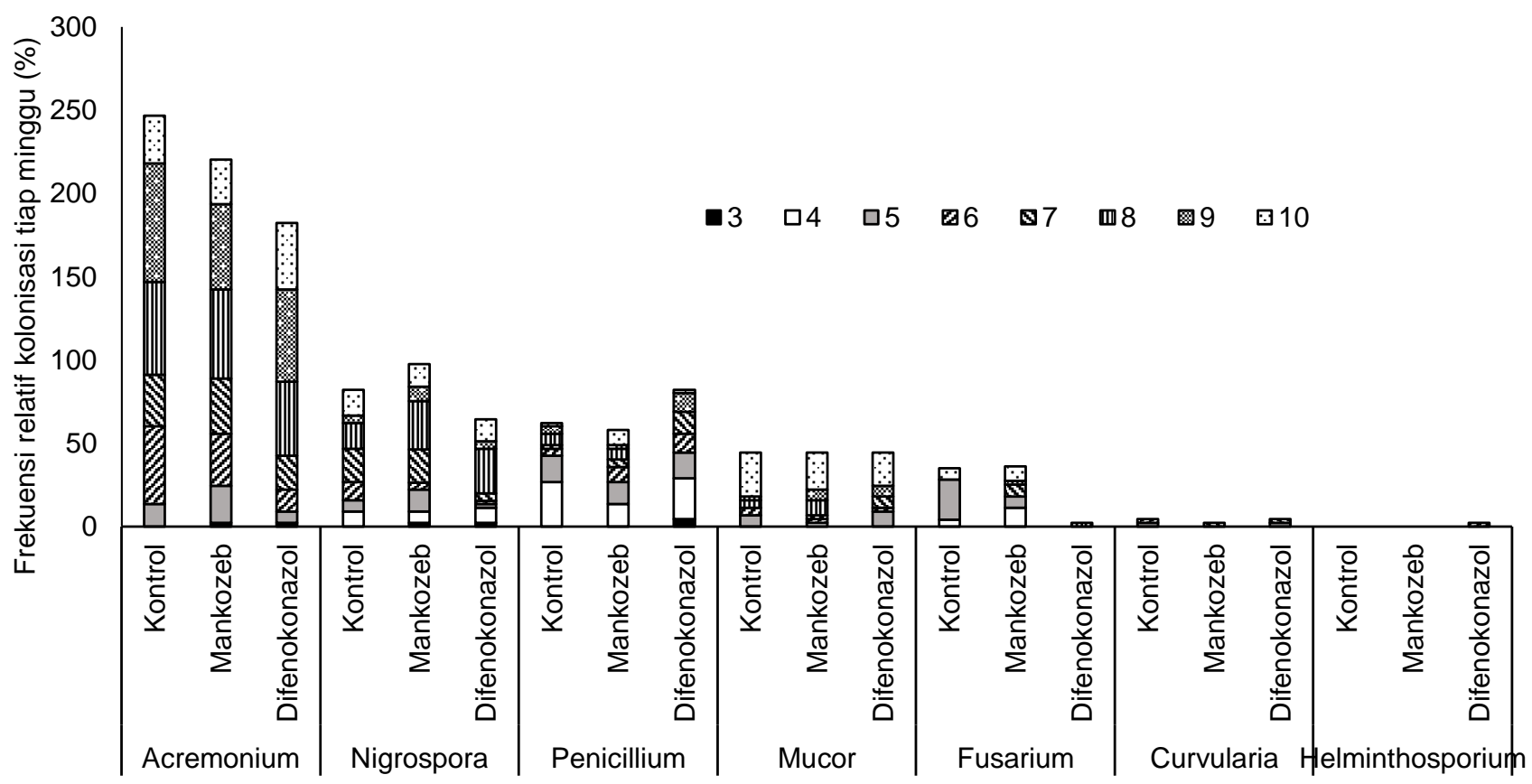

Gambar 5 Frekuensi relatif kolonisasi genus utama cendawan endofit batang padi tiap minggu (3-10 MST) pada tiap perlakuan.

yang sama juga ditunjukkan dalam penelitian ini. Frekuensi kolonisasi Fusarium menurun dengan perlakuan difenokonazol. Hasil rata-rata frekuensi kolonisasi Acremonium, Nigrospora, dan Fusarium juga menunjukkan penurunan dengan difenokonazol. Sementara pada perlakuan mankozeb, frekuensi kolonisasi endofit umumnya tidak menunjukkan adanya perubahan dibandingkan dengan kontrol. Cara kerja mankozeb (fungisida nonsistemik) yang terbatas pada permukaan tanaman kemungkinan memengaruhi hal tersebut.
Endofit merupakan salah satu komponen penting dalam ekosistem mikro tanaman, hidup mengolonisasi dan berinteraksi dengan inang, serta memberikan pengaruh yang positif lewat senyawa khusus yang dihasilkan untuk merangsang pertumbuhan dan memperkuat toleransi terhadap tekanan abiotik dan biotik inang (Jia et al. 2016). Semakin tua umur tanaman, kepadatan kolonisasi cendawan endofit juga semakin meningkat. Berdasarkan total cendawan endofit yang tumbuh dan indeks keanekaragaman, batang memiliki cendawan endofit yang lebih beragam dengan tingkat kolonisasi yang lebih tinggi diban- 
dingkan dengan daun. Kondisi sinar matahari yang rendah dengan kelembapan yang tinggi di sekitar batang kemungkinan menghasilkan lingkungan yang mendukung untuk kolonisasi dan reproduksi cendawan endofit (Wu et al. 2013). Kondisi batang yang lebih permanen mengakumulasi lebih banyak cendawan endofit dibandingkan dengan daun sehingga terjadi penyebaran dan infeksi berulang cendawan endofit (Sun et al. 2012).

Perlakuan fungisida umumnya tidak berpengaruh nyata pada frekuensi kolonisasi cendawan endofit pada daun. Akan tetapi, hasil rata-rata frekuensi kolonisasi cendawan endofit pada daun lebih tinggi pada kontrol dibandingkan dengan pada perlakuan fungisida. Pada batang, fungisida difenokonazol menurunkan Nigrospora dan Fusarium secara nyata pada saat tanaman berumur di bawah 7 MST. Pada umur ini merupakan fase yang penting bagi pertumbuhan dan perkembangan padi. Beberapa hama dan patogen penyebab penyakit akan menyerang atau menginfeksi padi pada fase ini, seperti penyakit blas, bercak cokelat sempit, busuk pelepah, wereng, penggerek batang, ulat grayak, dan lain-lain. Beberapa cendawan endofit dilaporkan memengaruhi ketahanan padi terhadap hama dan penyakit. Sebagai contoh, Nigrospora memberikan pengaruh negatif pada biologi wereng batang cokelat, seperti memperpanjang lama stadia nimfa, siklus hidup jantan dan betina, periode praoviposisi oviposisi, menunda umur betina pada saat meletakkan telur pertama kali, serta menurunkan kesintasan telur (Budiprakoso 2010; Mawan et al. 2015). Oleh karena itu, penurunan Nigrospora dan Fusarium pada fase vegetatif dengan aplikasi difenokonazol akan menurunkan ketahanan padi terhadap hama wereng cokelat, patogen, dan menurunkan pertumbuhan vegetatif padi. Hasil pengujian in vivo oleh Sucipto (2016) diperoleh bahwa Fusarium sp. Berpotensi mengendalikan penyakit blas dengan tingkat penekanan intensitas penyakit sebesar $30-40 \%$. Beberapa cendawan endofit dilaporkan mampu meningkatkan pertumbuhan padi (Plant Growth Promoting Fungi/PGPF). Fusarium, Acremonium, dan Penicillium mampu meningkatkan perkecambahan benih, tinggi tanaman, panjang akar, bobot biomassa, dan jumlah anakan (Khairy 2012; Waruwu 2016; Sucipto 2016). Kemampuan endofit sebagai PGPF juga berasosiasi dengan kemampuannya menginduksi ketahanan tanaman terhadap patogen (Yadav 2018).

\section{KESIMPULAN}

Kolonisasi cendawan endofit di dalam jaringan padi semakin meningkat seiring dengan pertambahan usia tanaman. Berdasarkan segmen yang dikolonisasi cendawan endofit dan indeks keanekaragaman cendawan endofit, batang memiliki cendawan endofit yang lebih beragam dari pada daun. Aplikasi fungisida mankozeb dan difenokonazol tidak memengaruhi secara nyata frekuensi kolonisasi dan indeks keanekaragaman cendawan endofit. Genus Nigrospora dan Fusarium mengalami penurunan dengan difenokonazol pada batang selama fase vegetatif.

\section{DAFTAR PUSTAKA}

Afandhi A, Choliq FA, Anggrilika WSH, Tarno H. 2018. Distribution of the endophytic fungi in apple leaves. AGRIVITA Journal of Agricultural Science. 40(1): 91-100. https://doi.org/10.17503/agrivita.v40i1. 1563

Ariyanto EF, Abadi AL, Djauhari S. 2013. Keanekaragaman jamur endofit pada daun tanaman Padi (oryza sativa L.) dengan sistem pengelolaan hama terpadu (PHT) dan konvensional di Desa Bayem, Kecamatan Kasembon, Kabupaten Malang. Jurnal Hama Penyakit Tumbuhan. 1(2): 37-50.

Arnold AE, Maynard Z, Gilbert GS. 2001. Fungal endophytes in dicotyledonous neotropical trees: patterns of abundance and diversity. Mycological Research. 105: 1502-1507. https://doi.org/10. 1017/S0953756201004956

Budiprakoso B. 2010. Pemanfaatan cendawan endofit sebagai penginduksi ketahanan tanaman padi terhadap wereng cokelat Nilaparvata lugens (Stal). (Hemiptera: Delphacidae). [Skripsi]. Bogor (ID): IPB.

Cadez N, Zupan J, Raspor P. 2010. The effect of fungicides on yeast communities associated with grape berries. FEMS Yeast Research. 10: 619-630. https://doi.org/10.1111/j.1567-1364.2010.006 35.x

Domsch KH, Gams W, Heidi T. 1980. Compendium of Soil Fungi. London (UK): Academic Press.

Fuchs B, Krischke M, Mueller MJ, Krauss J. 2017. Plant age and seasonal timing determine endophyte growth and alkaloid biosynthesis. Fungal Ecology. 29: 52-58. https://doi.org/10.1016/j.funeco. 2017.06.003

Gamboa MA, Laureano S, Bayman P. 2002. Measuring diversity of endophytic fungi in leaf fragments: does size matter? Mycopathologia. 156: 41-45. https:// doi.org/10.1023/A:1021362217723

Gotz M, Nirenberg H, Kraise S, Wotters H, Draeger S, Buchner A, Lottmann J, Berg G, Smalla K. 2006. Fungal endophytes in potato roots studied by traditional isolation and cultivation-independent DNA-based methods. FEMS Microbiology Ecology. 58(3): 404-413. https://doi.org/10.1111/j.15746941.2006.00169.x 
Hartley SE, Gange AC. 2009. Impacts of plant symbiotic fungi on insect herbivores: mutualism in a multitrophic context. Annual Review of Entomology. 54: 323-342. https://doi.org/10.1146/annurev. ento.54.110807.090614

Jia M, Chen L, Xin HL, Zheng CJ, Rahman K, Han T, Qin LP. 2016. A friendly relationship between endophytic fungi and medicinal plants: a systematic review. Frontiers in Microbiology. 7(906): 1-4 https://doi.org/10.3389/fmicb.2016.00906

Khairy M. 2012. Pengaruh cendawan endofit terhadap hama dan pertumbuhan tanaman padi di lapangan. [Skripsi]. Bogor (ID): IPB.

Koomnok C, Teaumroong N, Rerkasem B, Lumyong S. 2007. Diazotroph endophytic bacteria in cultivated and wild rice in Thailand. Science Asia. 33: 429-435. https://doi.org/10.2306/scienceasia15 131874.2007.33.429

Krebs CJ. 1989. Ecological Methodology. Di dalam Rahman A, Mujiyanto. 2013. Komunitas fitoplankton di Taman Nasional Karimun Jawa, Jepara, Jawa Tengah. Widyariset. 16(3): 395-402.

Kumar MKP, Gowda DKS, Moudgal R, Kumar NK, Gowda KTP, Vishwanath K. 2013. Impact of fungicides on rice production in India. In Nita M, editors Fungicides - Showcases of Integrated Plant Disease Management from Around the World. Edition 1. India (IN): In Tech. https://doi.org/ $10.5772 / 51009$

Magurran AE. 1988. Ecological Diversity and Its Measurement. New Jersey (US): Princeton University Press. https://doi.org/10.1007/978-94015-7358-0

Malandrakis A, Daskalaki ER, Skiadac V, Papadopoulouc KK, Kavroulakisb N. 2018. A Fusarium solani endophyte vs fungicides: compatibility in a Fusarium oxysporum f.sp. radicislycopersici-tomato pathosystem. Fungal Biology. 122(12): 1215-1221. https://doi.org/10.1016/ j.funbio.2018.10.003

Mawan A, Buchori D, Triwidodo H. 2015. Pengaruh cendawan endofit terhadap biologi dan statistik demografi wereng batang cokelat Nilaparvata lugens Stal. (Hemiptera: Delphacidae). Jurnal Entomologi Indonesia. 12(1): 11-19. https:// doi.org/10.5994/jei.12.1.11

Mohandoss J, Suryanarayanan TS. 2009. Effect of fungicide treatment on foliar fungal endophyte diversity in mango. Sydowia. 61: 11-24.

Naik BS, Shashikala J, Krishnamurthy YL. 2009. Study on the diversity of endophytic communities from rice (Oryza sativa L.) and their antagonistic activities in vitro. Microbiological Research. 164: 290-296. https://doi.org/10.1016/j.micres.2006.12.003
Saiga S, Kodama Yukinobu, Takahashi H, Tsuiki M. 2003. Endophyte removal by fungicides from tamets of perennial ryegrass and tall fescue. Grassland Science. 48(6): 504-509.

Saikkonen K, Ion D, Gyllenberg M. 2002. The persistence of vertically transmitted fungi in grass metapopulations. Proceedings of the Royal Society of London Series B. 269: 1397-1403. https:// doi.org/10.1098/rspb.2002.2006

Schulz B, Wanke U, Draeger S and Aust HJ. 1993. Endophytes from herbaceous plants and shrubs: effectiveness of surface sterilization methods. Mycology Research. 97(12): 1447-1450. https:// doi.org/10.1016/S0953-7562(09)80215-3

Sucipto I. 2016. Eksplorasi bakteri dan cendawan endofit sebagai agens pengendali penyakit blas (Pyricularia oryzae) pada padi sawah. [Tesis]. Bogor (ID): IPB. https://doi.org/10.14692/ jfi.11.6.211

Sudir, Suprihanto, Agus G, HM Toha. 2002. Pengaruh genotipe, pupuk, dan fungisida terhadap penyakit blas leher pada padi gogo. in Sudir, Nasution A, Santoso, Nuryanto B. 2014. Penyakit Blas Pyricularia grisea pada tanaman padi dan strategi pengendaliannya. Iptek Tanaman pangan. 9(2): 85-96.

Sun X, Ding Q, Hyde KD, Guo LD .2012. Community structure and preference of endophytic fungi of three woody plants in a mixed forest. Fungal Ecology. 5: 624-632. https://doi.org/10.1016/ j.funeco.2012.04.001

Sun X, Guo LD. 2012. Endophytic fungal diversity: review of traditional and molecular techniques. Mycology. 3(1): 65-76.

Waruwu AAS, Soekarno BPW, Munif A. 2016. Metabolit cendawan endofit tanaman padi sebagai alternatif pengendalian cendawan patogen terbawa benih padi. Jurnal Fitopatologi Indonesia. 12(2): 53-61. https://doi.org/10.14692/jfi.12.2.53

Watanabe T. 2002. Pictorial Atlas of Soil and Seed Fungi: Morphologies of Cultured Fungi and Key to Species. $2^{\text {nd }}$ edition. Florida (US): CRC Press LLC. https://doi.org/10.1201/9781420040821

Wu H, Yang HY, You XL, Li YH. 2013. Diversity of endophytic fungi from roots of Panax ginseng and their saponin yield capacities. Springerplus. 2(107): 1-9. https://doi.org/10.1186/2193-1801-2-107

Yadav AN. 2018. Biodiversity and biotechnological applications of host-specific endophytic fungi for sustainable agriculture and allied sectors. Acta Scientific Microbiology. 1(5):1-5.

Zakaria L, Yaakop AS, Salleh B, Zakaria M. 2010. Endophytic fungi from paddy. Tropical Life Sciences Research. 21(1): 101-107. 